OPEN ACCESS

Edited by:

John Orlowski,

McGill University, Canada

Reviewed by:

Hirokazu Oguni,

TMG Asaka Medical Center, Japan

Thea Giacomini

Giannina Gaslini Institute (IRCCS), Italy

*Correspondence:

Li Jiang

dr_jiangcqmu@163.com

Specialty section

This article was submitted to

Neurogenetics,

a section of the journa

Frontiers in Neurology

Received: 16 October 2021

Accepted: 17 December 2021

Published: 14 January 2022

Citation:

Liu X, Xie L, Fang Z and Jiang L (2022)

Case Report: Novel SLC9A6 Splicing

Variant in a Chinese Boy With

Christianson Syndrome With Electrical

Status Epilepticus During Sleep.

Front. Neurol. 12:796283

doi: 10.3389/fneur.2021.796283

\section{Case Report: Novel SLC9A6 Splicing Variant in a Chinese Boy With Christianson Syndrome With Electrical Status Epilepticus During Sleep}

\author{
Xiaorui Liu, Lingling Xie, Zhixu Fang and Li Jiang*
}

Ministry of Education Key Laboratory of Child Development and Disorders, Chongqing Key Laboratory of Pediatrics, Department of Neurology, National Clinical Research Center for Child Health and Disorders, Children's Hospital of Chongqing Medical University, Chongqing, China

We investigated the existence and potential pathogenicity of a SLC9A6 splicing variant in a Chinese boy with Christianson Syndrome (CS), which was reported for the first time in China. Trio whole-exome sequencing (WES) was performed in the proband and his parents. Multiple computer prediction tools were used to evaluate the pathogenicity of the variant, and reverse transcription-polymerase chain reaction (RT-PCR) analysis and cDNA sequencing were performed to verify the RNA splicing results. The patient presented with characteristic features of CS: global developmental delay, seizures, absent speech, truncal ataxia, microcephaly, ophthalmoplegia, smiling face and hyperkinesis with electrical status epilepticus during sleep (ESES) detected in an electroencephalogram (EEG). A SLC9A6 splicing variant was identified by WES and complete skipping of exon 10 was confirmed by RT-PCR. This resulted in altered gene function and was predicted to be pathogenic. ESES observed early in the disease course is considered to be a significant feature of CS with the SLC9A6 variant. Combined genetic analysis at both the DNA and RNA levels is necessary to confirm the pathogenicity of this variant and its role in the clinical diagnosis of CS.

Keywords: SLC9A6, Christianson syndrome, electrical status epilepticus during sleep, splicing mutation, reverse transcription-polymerase chain reaction

\section{INTRODUCTION}

The SLC9A6 gene(chrX:135098802), located on Xq26.3, encodes isoform 6 of the $\mathrm{Na}^{+} / \mathrm{H}^{+}$ exchanger superfamily (NHE6). NHE6 exchanges luminal $\mathrm{H}^{+}$in early and recycling endosomes, thus contributing to substance transport and receptor recycling, which are essential for axonal growth, branching, synaptic maturation and neural plasticity (1). Christianson syndrome (CS) has been associated with a SLC9A6 variant and is characterized by moderate to severe global developmental delay, epilepsy, absent or impaired speech, truncal ataxia, ophthalmoplegia, acquired microcephaly (2) and reduced life expectancy (3). The clinical features of CS overlap with those of Angelman syndrome (AS) (4), making it hard to identify in clinical practice. 
In this study, we identified a maternally-inherited SLC9A6 splicing variant in a Chinese boy who presented with global developmental delay, epilepsy and microcephaly. The wholeexome sequencing results were further verified by reverse transcription-polymerase chain reaction (RT-PCR) and cDNA sequencing. Our findings indicate the pathogenicity of this SLC9A6 splicing variant in CS.

\section{MATERIALS AND METHODS}

\section{Patients and Samples}

The proband was registered at the Department of Neurology of the Children's Hospital of Chongqing Medical University (China). Detailed neurological examinations were performed by at least two senior neurologists. Written informed consent was obtained from the participants, and the research project was approved by the Children's Hospital of Chongqing Medical University Ethics Committee. A normal sample was used as control.

\section{Whole-Exome Sequencing}

Genomic DNA was extracted from the peripheral blood cells of the proband and his parents, as well as the normal control using a DNA extraction kit (Tiangen, Beijing, China). Whole exome DNA was captured using IDT The xGen Exome Research Panel v2.0 and subsequently sequenced on an Illumina NextSeq 500 system with 101-bp paired-end reads to screen for variants. After duplicated reads were removed from downstream analysis, clean reads were aligned to GRCh37/hg19 human reference genome using NovoAlign software. SNP and small insertion or deletion (InDel) variants were detected and identified using the Genome Analysis Toolkit (5) and then were annotated using ANNOVAR. Variants which fulfilled the following criteria were considered candidate genes: (a) variants that were absent or rare (allele frequency <0.01) in the 1,000 Genomes Project, Exome Aggregation Consortium (ExAC) or GnomAD databases; (b) variants that affected the amino-acid sequence, such as frameshift, and splice site variants. The pathogenicity of the identified variants was then predicted using multiple algorithms prediction tools, such as PolyPhen-2, Mutation Taster, and Sorting Intolerant from Tolerant (SIFT), and classified according to the guidelines of American College of Medical Genetics and Genomics (ACMG) (6).

\section{Sanger Sequencing}

Sanger sequencing was performed to validate the potentially pathogenic variations identified in the patient and his parents to determine the parental origin. The phenotypes of the proband and his parents were verified according to published articles (1, 3, 7-13) and OMIM database (OMIM:300243).

\section{RNA Splicing Analysis by RT-PCR}

Multiple computer prediction tools (MaxEntScan, NNSPLICE, NetGene2, Alternative Splice Site Predictor, and FSPLICE) were used to evaluate the pathogenicity of variant. The RNA splicing results were verified by RT-PCR analysis and cDNA sequencing. Total RNA was extracted from the peripheral blood cells of the proband and normal control using an RNA extraction reagent kit (Tiangen, Beijing, China) and then converted into cDNA using the PrimeScript ${ }^{\mathrm{TM}}$ II 1 st strand cDNA synthesis kit (Takara Dalian, China). Primers were designed to amplify the target fragment of the SLC9A6 (forward: 5'-TACGGGAGTTCCAGTTGTTGG-3' and reverse: 5'AGGGGTSSSTSTTGGCAGCTCTT-3'). After being isolated by agarose gel electrophoresis, the purified PCR products were sequenced by Sanger sequencing.

\section{RESULTS}

\section{Clinical Presentation}

A Chinese boy was born at term with a birth weight of $2,950 \mathrm{~g}$ (25-50th centile) and head circumference of $32 \mathrm{~cm}$ (10-25th centile) without neonatal asphyxia at birth or aberrant family history. He developed complex febrile seizures at the age of 11 months, which manifested as a clustering of generalized tonic or tonic-clonic seizures (9 seizures within 2 days) lasting 15$60 \mathrm{~s}$. Prior to the onset of seizures, the patient presented with developmental delay. He was admitted to our hospital at the age of 17 months, when his weight was $10.5 \mathrm{~kg}$ (25th centile), and head circumference was $42 \mathrm{~cm}$ ( $<1$ st centile), indicating microcephaly, with strabismus, narrow face, small mandible and frequent smiling. A café-au-lait spot (diameter $2.5 \mathrm{~cm}$ ) was located on the lower left quadrant of the boy's abdomen. He could not stand independently or speak coherently. CS was diagnosed after SLC9A6 pathogenic variant identified by genetic analysis. An advanced clinical diagnosis was not given due to lack of sufficient cognition of this syndrome. Seizures were controlled for 3 months following treatment with valproate at $17 \mathrm{mg} /(\mathrm{kg} . \mathrm{d})$. Subsequently, afebrile seizure recurred almost once a month with the same type and duration as before. Valproate was increased to $45 \mathrm{mg} /(\mathrm{kg} . \mathrm{d})$ and Levetiracetam was included in the drug regimen when the patient was 1 year and 9 months old. At the last follow-up when the patient was 2 years and 10 months old, his seizures were controlled and this continued for more than 1 year although his electroencephalogram (EEG) remained abnormal. Rehabilitation training was performed but without adequate efficacy. The child had an ataxic gait, gradually developed hyperkinesis and was still unable to speak coherently.

\section{Electroencephalogram and Brain MRI Finding}

When the patient first experienced complex febrile seizures at the age of 11 months, the routine sleep EEG evaluation showed continuous spike-waves from the bilateral frontal regions, forming more than $80 \%$ of the sleep recording, which suggests the presence of electrical status epilepticus during slow wave sleep (ESES) (Figure 1). At that time, brain magnetic resonance imaging revealed widening of the extracerebral space at the bilateral temporal poles (Figure 2). ESES was still detected after the seizures were controlled for more than 1 year when he was 2 years and 10 months old and further confirmed during an overnight sleep EEG (Figure 1). 

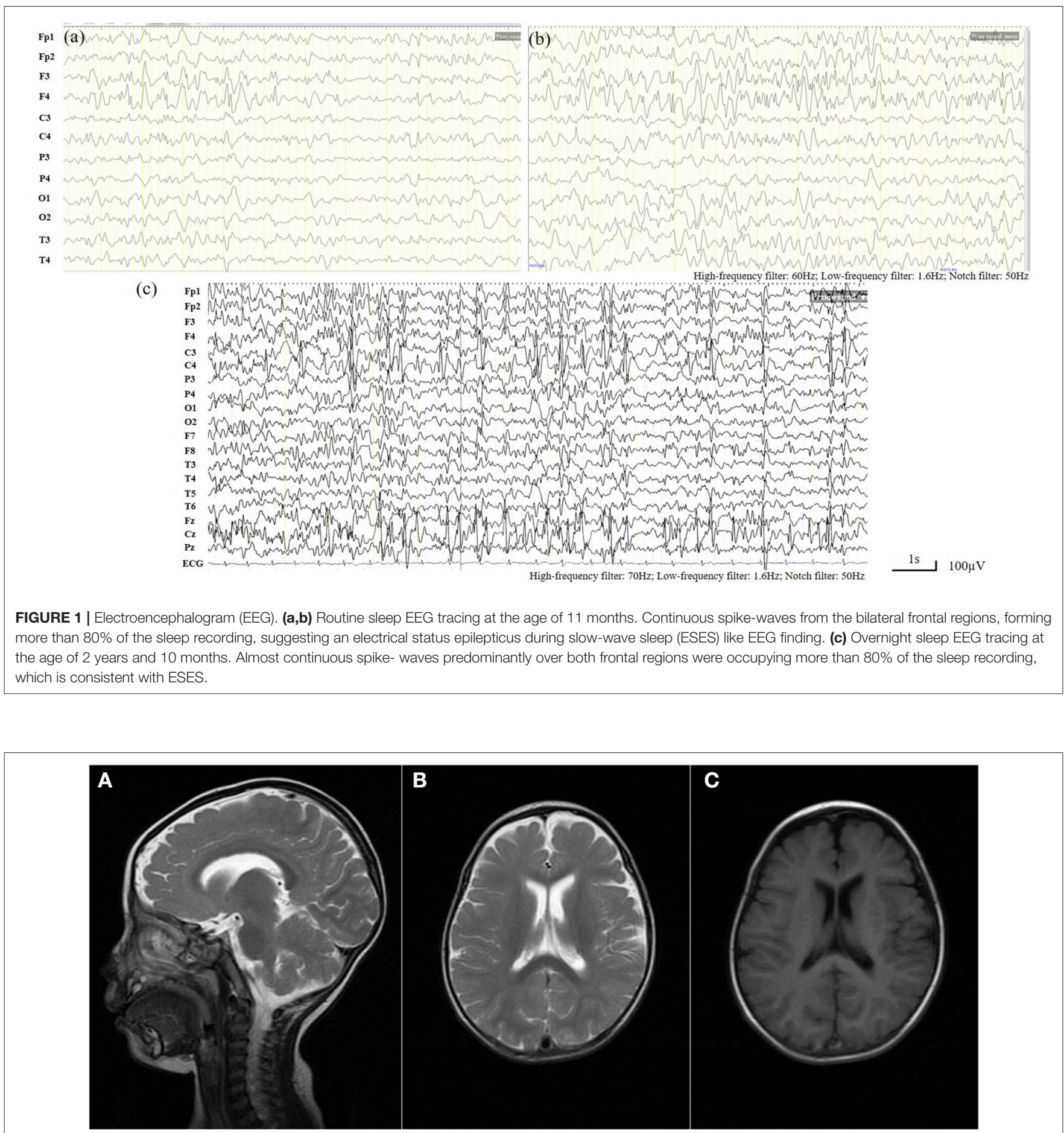

FIGURE 2 | Brain MRI finding at the age of 11 months. MRI [(A,B) T2, (C) T1] demonstrated the widening of the extracerebral space at the bilateral temporal poles.

\section{Molecular Studies}

Trio WES was performed on the patient and his parents, with written informed consent. A heterozygous, maternallyinherited SLC9A6 splicing pathogenic variant [c.1237-2 (IVS9)
A>G, NM_001042537] was identified and confirmed by Sanger sequencing. The variation was not present in the gnomAD, dbSNP, and ClinVar databases. At least three prediction tool algorithms predicted that this variant is associated with 


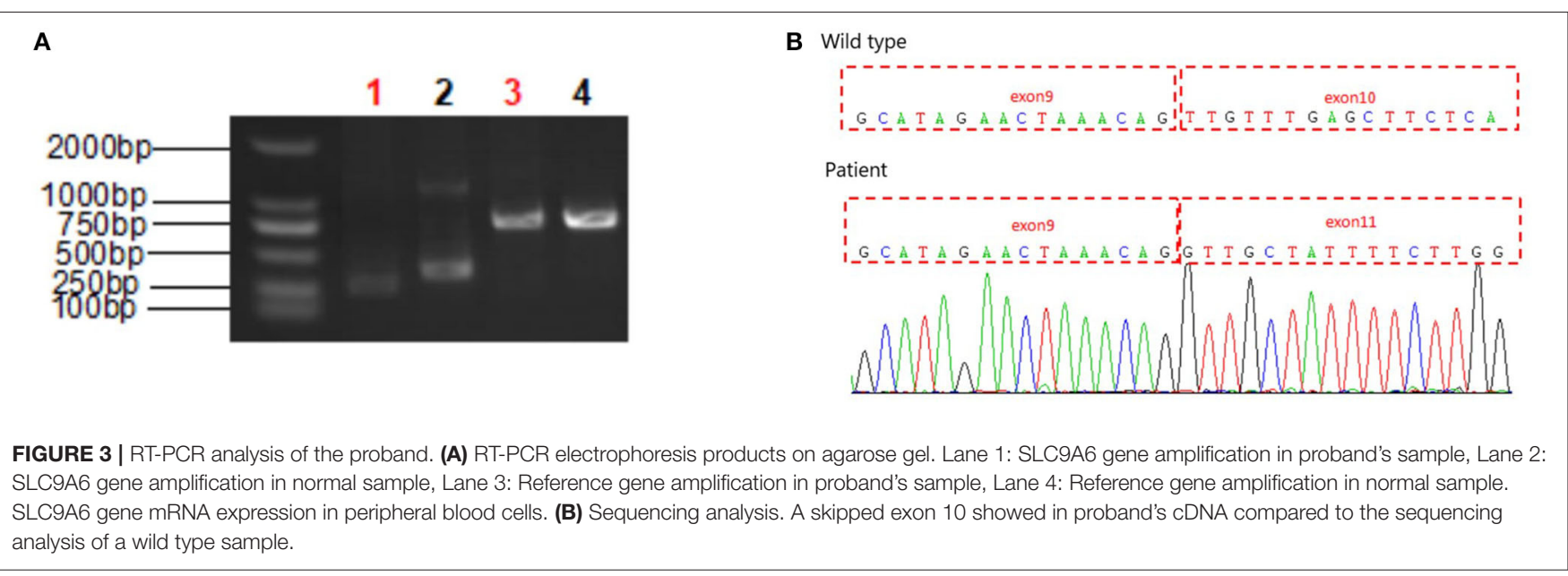

deleterious effects on the gene or gene products. These changes were classified as "pathogenic" (PVS1+PM2+PP3) according to ACMG criteria. His mother had the same variation bit in a heterozygous state and did not present any pathological clinical findings.

In silico analysis using multiple algorithms such as MaxEntScan, NNSPLICE, NetGene2, Alternative Splice Site Predictor, and FSPLICE predicted a strength reduction in the 3' acceptor site, which may disrupt the normal pre-RNA splicing.

To validate the RNA splicing prediction, we performed RTPCR analysis and CDNA sequencing of the RNA extracted from the peripheral blood cells of proband and normal sample. Separation to of the PCR product by agarose gel electrophoresis confirmed expression of the SLC9A6 gene transcript expressed in peripheral blood cells of the proband. PCR amplification and sequencing of the exons flanking the target loci confirmed abnormal splicing near the mutation site with complete skipping of exon 10 (Figure 3). This aberrant transcript resulted in a 38 amino-acid deletion (p.Leu381_Phe418del), and hence impaired the function of the NHE6 protein.

\section{DISCUSSION}

NHE6, encoded by SLC9A6, is predominantly located in early and recycling endosomes and operates as an alkalinizing mechanism that regulates luminal $\mathrm{H}^{+}$levels. This process is essential for ligand-receptor complex dissociation and dephosphorylation (13), which are crucial for synaptic maturation and neural plasticity. NHE6 abnormalities can also affect cell viability (14), possibly due to disruption of the balance of apoptosis as a result of endosomal dysfunction and attenuation of tyrosine receptor kinase B (TrkB) signaling (8), although the mechanism remains to be elucidated. SlC9A6 knockout mice presented an abnormal accumulation of GM2 ganglioside and unesterified cholesterol within late endosomes and lysosomes, with slow degeneration of neurons in the hippocampus, some areas of cerebral cortex and
TABLE 1 | Differential characteristics between Christianson syndrome and Angelman syndrome.

\begin{tabular}{|c|c|c|}
\hline & $\begin{array}{l}\text { Christianson } \\
\text { syndrome }\end{array}$ & Angelman syndrome \\
\hline \multirow[t]{2}{*}{ Gene } & SLC9A6 & Maternal gene UBE3A \\
\hline & & $\begin{array}{l}\text { Chromosome } \\
15 q 11.2-q 13\end{array}$ \\
\hline Gender & Male & No gender preference \\
\hline Seizure & Yes & Yes \\
\hline Psychomotor delay & Yes & Yes \\
\hline Speech deficits & Yes & Yes \\
\hline Developmental regression & Motor regression & No \\
\hline Intellectual disability & Always severe & Variable \\
\hline Acquired microcephaly & Yes & $\begin{array}{l}\text { Majority (more common } \\
\text { in the deletion subtype) }\end{array}$ \\
\hline Happy demeanor & Possible & $\begin{array}{l}\text { Yes, often with } \\
\text { hand-flapping } \\
\text { movements }\end{array}$ \\
\hline Facial features & $\begin{array}{l}\text { Long thin face, quint, } \\
\text { prominent jaw }\end{array}$ & $\begin{array}{l}\text { Flat occiput, wide } \\
\text { mouth, widely spaced } \\
\text { teeth, protruding } \\
\text { tongue, prognathism, } \\
\text { hypopigmented }\end{array}$ \\
\hline Strabismus & Yes & Possible \\
\hline Ataxic gait & Yes & $\begin{array}{l}\text { Yes and/or tremulous } \\
\text { movement of the limbs }\end{array}$ \\
\hline Hyperkinesis & Yes & Yes \\
\hline Autistic features & Yes & Possible \\
\hline Sleep disturbances & Possible & Yes \\
\hline Weight gain & Poor & $\begin{array}{l}\text { Poor in early childhood, } \\
\text { normal or even obesity } \\
\text { in young adulthood }\end{array}$ \\
\hline $\begin{array}{l}\text { Progressive cerebellar } \\
\text { atrophy }\end{array}$ & Yes & No \\
\hline ESES & Possible & No \\
\hline Life span & shorter & normal \\
\hline
\end{tabular}

ESES, electrical status epilepticus during sleep. 
TABLE 2 | Clinical characteristics of 8 cases of CS with ESES.

\begin{tabular}{|c|c|c|c|c|c|c|c|c|c|c|c|c|c|c|}
\hline Cases & & Gender & $\begin{array}{l}\text { Age at } \\
\text { epilepsy } \\
\text { onset }\end{array}$ & $\begin{array}{l}\text { Seizure } \\
\text { type }\end{array}$ & Status & $\begin{array}{l}\text { Seizure } \\
\text { frequency }\end{array}$ & $\begin{array}{l}\text { Resistance } \\
\text { to AEDs }\end{array}$ & AEDs & Clinical features & $\begin{array}{l}\text { Age at } \\
\text { ESES }\end{array}$ & $\begin{array}{l}\text { Age at ESES } \\
\text { resolution }\end{array}$ & Development & $\begin{array}{l}\text { Brain } \\
\text { imaging }\end{array}$ & $\begin{array}{l}\text { Genetic } \\
\text { analysis }\end{array}$ \\
\hline 1 & $\begin{array}{l}\text { Mathieu et al. } \\
\text { (15) }\end{array}$ & Male & 13 months & $\begin{array}{l}\text { GTCS, } \\
\text { myoclonic }\end{array}$ & NK & $\begin{array}{l}\text { Yearly to free } \\
\text { at } 12 \mathrm{y}\end{array}$ & Yes & $\begin{array}{l}\text { VPA, CLB, } \\
\text { LEV, ESM, } \\
\text { LTG }\end{array}$ & $\begin{array}{l}\text { Delayed } \\
\text { psychomotor } \\
\text { development, no } \\
\text { oral speech, ataxia } \\
\text { gait, motor } \\
\text { regression at } 11 \text { y, } \\
\text { frequent smiling, } \\
\text { microcephaly, low } \\
\text { weight, } \\
\text { dysmorphic } \\
\text { features including } \\
\text { long thin face, } \\
\text { quint, prominent } \\
\text { jaw }\end{array}$ & 6 y & $8 y$ & $\begin{array}{l}\text { Moderate to } \\
\text { severe ID }\end{array}$ & $\begin{array}{l}\text { Slight } \\
\text { enlargement } \\
\text { of } \\
\text { subarachnoid } \\
\text { spaces, } \\
\text { mostly in } \\
\text { bitemporal } \\
\text { regions, and a } \\
\text { left temporal } \\
\text { arachnoid } \\
\text { cyst. (at } 18 \mathrm{~m} \text { ) }\end{array}$ & $\begin{array}{l}\text { 40-Mb deletion } \\
\text { in Xq26.3 }\end{array}$ \\
\hline 2 & $\begin{array}{l}\text { Mathieu et al. } \\
\text { (15) }\end{array}$ & Male & 20 months & GTCS & Yes & Monthly & Yes & $\begin{array}{l}\text { VPA, LEV, } \\
\text { CLB }^{*}\end{array}$ & $\begin{array}{l}\text { Delayed } \\
\text { psychomotor } \\
\text { development, } \\
\text { autistic features, } \\
\text { no oral speech }\end{array}$ & 4 y $10 m$ & NK & $\begin{array}{l}\text { Moderate to } \\
\text { severe ID }\end{array}$ & $\begin{array}{l}\text { Normal (at } \\
22 \mathrm{~m} \text { ) }\end{array}$ & c. $1569 \mathrm{G}>\mathrm{A}$ \\
\hline 3 & $\begin{array}{l}\text { Mathieu et al. } \\
\text { (15) }\end{array}$ & Male & 17 months & $\begin{array}{l}\text { Partial } \\
\text { seizures, } \\
\text { GTCS }\end{array}$ & NK & NK & Yes & $\begin{array}{l}\text { VPA, LTG, } \\
\text { OXC, CLB* }\end{array}$ & $\begin{array}{l}\text { Delayed } \\
\text { psychomotor } \\
\text { development, on } \\
\text { oral speech, ataxia } \\
\text { gait, } \\
\text { underutilization of } \\
\text { the right hand, } \\
\text { sleep difficulties }\end{array}$ & 4 y & NK & $\begin{array}{l}\text { Moderate to } \\
\text { severe ID }\end{array}$ & $\begin{array}{l}\text { Normal (at } \\
3 \mathrm{y})\end{array}$ & $\begin{array}{l}\text { c.1148G>A } \\
\text { (p.Gly383Asp) }\end{array}$ \\
\hline 4 & $\begin{array}{l}\text { Zanni et al. } \\
\text { (10) }\end{array}$ & Male & $<2$ years & TCS & NK & NK & Yes & NK & $\begin{array}{l}\text { Delayed motor } \\
\text { development, no } \\
\text { oral speech, } \\
\text { autistic features, } \\
\text { microcephaly, } \\
\text { severe hypotonia, } \\
\text { ataxia gait, motor } \\
\text { regression at } 7 \text { y }\end{array}$ & $7 y$ & NK & $\begin{array}{l}\text { Moderate to } \\
\text { severe ID }\end{array}$ & $\begin{array}{l}\text { Cerebellar } \\
\text { vermin } \\
\text { atrophy, } \\
\text { cerebral and } \\
\text { hippocampi } \\
\text { atrophy (at } 7 \\
\text { y) }\end{array}$ & $\begin{array}{l}\text { c. } 1151- \\
1 \mathrm{G}>\mathrm{A}(\mathrm{V} 1 \mathrm{10}-1 \\
\mathrm{G}>\mathrm{A})\end{array}$ \\
\hline 5 & $\begin{array}{l}\text { Coorg et al. } \\
\text { (19) }\end{array}$ & Male & 12 months & $\begin{array}{l}\text { complex } \\
\text { motor } \\
\text { seizures, } \\
\text { TCS }\end{array}$ & Yes & $\begin{array}{l}\text { Yearly to free } \\
\text { at } 8 \text { y (after } \\
\text { initiation of } \\
\text { felbamate) }\end{array}$ & No & $\begin{array}{l}\text { CBZ, LEV, } \\
\text { VPA, CLB, } \\
\text { Felbamate }\end{array}$ & $\begin{array}{l}\text { delayed global } \\
\text { development, } \\
\text { microcephaly, } \\
\text { autistic features, } \\
\text { sleep difficulty }\end{array}$ & $8 y$ & NK & $\begin{array}{l}\text { Moderate to } \\
\text { severe ID }\end{array}$ & $\begin{array}{l}\text { Normal (at } 12 \\
\text { and } 28 \mathrm{~m} \text { ) }\end{array}$ & $\begin{array}{l}\text { c. } 1710 G>A \\
\left.\text { (p. } \operatorname{Trp} 570^{*}\right)\end{array}$ \\
\hline
\end{tabular}


TABLE 1 | Continued

\begin{tabular}{|c|c|c|c|c|c|c|c|c|c|c|c|c|c|c|}
\hline Cases & & Gender & $\begin{array}{l}\text { Age at } \\
\text { epilepsy } \\
\text { onset }\end{array}$ & $\begin{array}{l}\text { Seizure } \\
\text { type }\end{array}$ & Status & $\begin{array}{l}\text { Seizure } \\
\text { frequency }\end{array}$ & $\begin{array}{l}\text { Resistance } \\
\text { to AEDs }\end{array}$ & AEDs & Clinical features & $\begin{array}{l}\text { Age at } \\
\text { ESES }\end{array}$ & $\begin{array}{l}\text { Age at ESES } \\
\text { resolution }\end{array}$ & Development & $\begin{array}{l}\text { Brain } \\
\text { imaging }\end{array}$ & $\begin{array}{l}\text { Genetic } \\
\text { analysis }\end{array}$ \\
\hline 6 & Ikeda et al. (3) & Male & 17 months & $\begin{array}{l}\text { GTCS, } \\
\text { atonic } \\
\text { seizures }\end{array}$ & NK & Daily & Yes & $\begin{array}{l}\text { VPA, CLB, } \\
\text { TPM, LTG, } \\
\text { LEV, CBZ, } \\
\text { Rufinamide }\end{array}$ & $\begin{array}{l}\text { Delayed } \\
\text { psychomotor } \\
\text { development, } \\
\text { microcephaly, no } \\
\text { oral speech, ataxia } \\
\text { gait, truncal } \\
\text { hypotonia, } \\
\text { hyperkinesis }\end{array}$ & $7 y$ & NK & Severe ID & $\begin{array}{l}\text { T2 } \\
\text { hyperintensity } \\
\text { and atrophy } \\
\text { of the lower } \\
\text { cerebellum (at } \\
6 \text { y) }\end{array}$ & $\begin{array}{l}\text { c.477_481del } \\
\text { (p.lle160Leufs }{ }^{5} \text { ) }\end{array}$ \\
\hline 7 & $\begin{array}{l}\text { Gong et al. } \\
\text { (18) }\end{array}$ & Male & $\begin{array}{l}1 \text { year } 11 \\
\text { months }\end{array}$ & $\begin{array}{l}\text { Focal } \\
\text { seizure, } \\
\text { febrile } \\
\text { GTCS, } \\
\text { myoclonic } \\
\text { seizures, } \\
\text { atypical } \\
\text { seizures }\end{array}$ & NK & Uncontrolled & Yes & VPA, LEV & $\begin{array}{l}\text { Delayed } \\
\text { psychomotor } \\
\text { development, } \\
\text { ataxia gait, on oral } \\
\text { speech, } \\
\text { hyperkinesis }\end{array}$ & 3 y 3 m & NK & NK & $\begin{array}{l}\text { Normal (age } \\
\text { NK) }\end{array}$ & $\begin{array}{l}\text { c.1178_1180del } \\
\text { (p.394del) }\end{array}$ \\
\hline 8 & Case & Male & 11 months & $\begin{array}{l}\text { Febrile } \\
\text { GTCS, } \\
\text { GTCS }\end{array}$ & No & $\begin{array}{l}\text { Monthly to } \\
\text { free at } 1 \text { year } \\
9 \text { months } \\
\text { (after initiation } \\
\text { of LEV) }\end{array}$ & No & VPA, LEV & $\begin{array}{l}\text { Delayed } \\
\text { psychomotor } \\
\text { development, no } \\
\text { oral speech, } \\
\text { microcephaly, } \\
\text { ataxia gait, } \\
\text { hyperkinesis, } \\
\text { frequent smiling, } \\
\text { dysmorphic } \\
\text { features including } \\
\text { narrow face, } \\
\text { strabismus, small } \\
\text { mandible, } \\
\text { café-au-lait spot. }\end{array}$ & $\begin{array}{l}\text { ESES- } \\
\text { like at } \\
11 \mathrm{~m}, \\
\text { ESES } \\
\text { diagnosed } \\
\text { at } 2 \mathrm{y} \\
10 \mathrm{~m}\end{array}$ & NK & $\begin{array}{l}\text { Moderate to } \\
\text { severe ID }\end{array}$ & $\begin{array}{l}\text { Widening of } \\
\text { the } \\
\text { extracerebral } \\
\text { space at the } \\
\text { bilateral } \\
\text { temporal } \\
\text { poles (at } \\
11 \mathrm{~m} \text { ) }\end{array}$ & $\begin{array}{l}\text { c. } 1237-2 A>G \\
\text { (IVS9 } A>G)\end{array}$ \\
\hline
\end{tabular}

This table includes all previously published reports of Christianson Syndrome with ESES. EEG, electroencephalogram; AEDs, anti-epileptic drugs; ESES, electrical status epilepticus during sleep; ID, intellectual disability; y, years; $m$, months; GTCS, generalized tonic-clonic seizures; TCS, tonic-clonic seizures; NK, unknown; VPA, valproic acid; CLB, clobazam; LEV, levetiracetam; CBZ, carbamazepine; ESM, ethosuximide; TPM, topiramate; LTG, lamotrigine; OXC, oxcarbazepine. "negative behavioral impact. 
cerebellar Purkinje cells and a CS-like clinical phenotype (7). In addition to NHE6 loss-of-function mutations, which have been confirmed to be correlated to the pathophysiology of CS with SLC9A6 variants, NHE6 gain-of-function mutations have also been reported to be associated with impairment of optimal recycling endosomal function, accounting for the pathophysiology of CS (12).

This is the first report of CS caused by a SLC9A6 pathogenic variant in a patient in China. SLC9A6 variants are correlated with various neurological diseases, including CS, autism spectrum disorders, schizophrenia and idiopathic Parkinson's disease (13). The correlation with CS has been well-established. CS follows a X-linked recessive inheritance pattern, with clinical features that overlap with those of AS in male patients presenting with moderate to severe global developmental delay, epilepsy, absent or impaired speech, truncal ataxia, ophthalmoplegia, acquired microcephaly, hyperkinesis, cerebellar atrophy and reduced life expectancy (Table 1) (1, 3, 7-13). Seizure onset usually occurs in late infancy. Tonic/tonic-clonic seizures are the most common types, although atonic seizures, myoclonic seizures and focal seizures have also been described (3). Phenotypes of Lennox-Gastaut syndrome are relatively common in CS patients, especially those with ESES (3). A case with spasms and hypsarrhythmia detected by EEG was also reported and classified as infantile spasms (14). There is very little information about the course of seizure development. However, there are some reports of spontaneous attenuation during adolescence (15), although moderate-to-severe intellectual disability and other neurologic abnormalities remain. Female carriers usually have a normal-to-mild phenotype with differences in penetrance and enhanced effects on progeny $(16,17)$. Our patient also presented with global developmental delay, generalized tonic/tonic-clonic seizures, absent speech, truncal ataxia, acquired microcephaly, ophthalmoplegia, smiling face and hyperkinesis, which is consistent with previous reports. His mother carried the same variation in a heterozygous state and presented with a normal phenotype.

Generalized slow spike-wave complexes as a predominantly interictal EEG feature of patients with SLC9A6 variants and the presentation of ESES during early childhood (3 years 3 months -8 years) $(3,10,15,18,19)$ was first described in 2014 (10). The characteristics of CS with ESES reported so far were summarized in Table 2. Patients with ESES are usually refractory to anti-epileptic drugs. Rohini et al. (19) reported resolution of ESES following felbamate treatment in a child with a SLC9A6 variant. In our patient, who was much younger than those previously described, ESES-like EEG finding was present from the first episode of complex febrile seizures and was further confirmed without much attenuation after the seizures were controlled for more than 1 year. Thus, combined with the characteristic clinical presentation, ESES or ESES-like EEG finding is implicated as a valuable diagnostic indicator of the SLC9A6 mutation.

More than 80 genetic variants of SLC9A6 have been reported to date. The most common pathogenic variants are protein-truncating mutations, such as frameshift or non-sense mutations and splicing mutations in transmembrane ion translocation domain (amino acid 25-533), which lead to partial or complete loss of NHE6 function (14). Pathogenic missense variants, small inframe deletions or non-sense mutations in the $\mathrm{C}$-terminal cytoplasmic regulatory domain are relatively less common $(1,13)$. Genotype-phenotype correlations have not yet been established in CS. The c.1237-2 (IVS9) $A>G$ variant is a canonical splice site mutation associated with exon 10 skipping, leading to a 38-amino-acid deletion (p.Leu381_Phe418del). Exon 10 in SLC9A6 encodes the transmembrane ion translocation domain that interacts with the angiotensin II type 2 receptor (AGTR2) (10). Mutations in this region are associated with intellectual disability and epilepsy, although the underlying mechanisms remain to be investigated. Recently, arborization phenotypes were found to be rescued by the application of exogenous trophic factors (BDNF) across all type of SLC9A6 mutation (20). Restraining over-acidification of endosomes and aberrant substance transportation or lysosomal degradation could also be potential therapeutic strategies for the treatment of CS patients with SLC9A6 pathogenic variants.

\section{CONCLUSION}

ESES observed early in the disease course is considered to be a significant feature of CS with the SLC9A6 variants. Combined genetic analysis at both the DNA and RNA levels is necessary to confirm the pathogenicity of this variant and its role in the clinical diagnosis of CS.

\section{DATA AVAILABILITY STATEMENT}

The datasets presented in this article are not readily available due to ethical and privacy restrictions. Requests to access the datasets should be directed to the corresponding author.

\section{ETHICS STATEMENT}

The studies involving human participants were reviewed and approved by Children's Hospital of Chongqing Medical University Ethics Committee. Written informed consent to participate in this study was provided by the participants' legal guardian/next of kin. Written informed consent was obtained from the minor(s)' legal guardian/next of kin for the publication of any potentially identifiable images or data included in this article.

\section{AUTHOR CONTRIBUTIONS}

XL: study conception and design, genetic testing, analysis of data, and drafting of manuscript. LX: genetic testing, analysis of data, and critical revision. ZF: acquisition of data, genetic testing, analysis of data, and critical revision. LJ: study conception and design, analysis of data, and critical revision. All authors contributed to the article and approved the submitted version. 


\section{REFERENCES}

1. Gao AYL, Ilie A, Chang PKY, Orlowski J, McKinney RA. A Christianson syndrome-linked deletion mutation $(\Delta 287 \mathrm{ES} 288)$ in SLC9A6 impairs hippocampal neuronal plasticity. Neurobiol Dis. (2019) 130:104490. doi: 10.1016/j.nbd.2019.104490

2. Seltzer LE, Paciorkowski AR. Genetic disorders associated with postnatal microcephaly. Am J Med Genet C Semin Med Genet. (2014) 166c:14055. doi: 10.1002/ajmg.c.31400

3. Ikeda A, Yamamoto A, Ichikawa K, Tsuyusaki Y, Tsuji M, Iai M, et al. Epilepsy in Christianson syndrome: Two cases of Lennox-Gastaut syndrome and a review of literature. Epilepsy Behav Rep. (2020) 13:100349. doi: 10.1016/j.ebr.2019.100349

4. Takahashi Y, Hosoki K, Matsushita M, Funatsuka M, Saito K, Kanazawa $\mathrm{H}$, et al. A loss-of-function mutation in the SLC9A6 gene causes X-linked mental retardation resembling Angelman syndrome. Am J Med Genet B Neuropsychiatr Genet. (2011) 156b:799-807. doi: 10.1002/ajmg.b.31221

5. DePristo MA, Banks E, Poplin R, Garimella KV, Maguire JR, Hartl C, et al. A framework for variation discovery and genotyping using next-generation DNA sequencing data. Nat Genet. (2011) 43:491-8. doi: 10.1038/ng.806

6. Richards S, Aziz N, Bale S, Bick D, Das S, Gastier-Foster J, et al. Standards and guidelines for the interpretation of sequence variants: a joint consensus recommendation of the American College of Medical Genetics and Genomics and the Association for Molecular Pathology. Genet Med. (2015) 17:40524. doi: 10.1038/gim.2015.30

7. Strømme P, Dobrenis K, Sillitoe RV, Gulinello M, Ali NF, Davidson C, et al. X-linked Angelman-like syndrome caused by Slc9a6 knockout in mice exhibits evidence of endosomal-lysosomal dysfunction. Brain. (2011) 134:3369-83. doi: 10.1093/brain/awr250

8. Ouyang Q, Lizarraga SB, Schmidt M, Yang U, Gong J, Ellisor D, et al. Christianson syndrome protein NHE6 modulates TrkB endosomal signaling required for neuronal circuit development. Neuron. (2013) 80:97112. doi: 10.1016/j.neuron.2013.07.043

9. Riess A, Rossier E, Krüger R, Dufke A, Beck-Woedl S, Horber V, et al. Novel SLC9A6 mutations in two families with Christianson syndrome. Clin Genet. (2013) 83:596-7. doi: 10.1111/j.1399-0004.2012.01948.x

10. Zanni G, Barresi S, Cohen R, Specchio N, Basel-Vanagaite L, Valente $\mathrm{EM}$, et al. A novel mutation in the endosomal $\mathrm{Na}+/ \mathrm{H}+$ exchanger NHE6 (SLC9A6) causes Christianson syndrome with electrical status epilepticus during slow-wave sleep (ESES). Epilepsy Res. (2014) 108:8115. doi: 10.1016/j.eplepsyres.2014.02.009

11. Ieda D, Hori I, Nakamura Y, Ohashi K, Negishi Y, Hattori A, et al. A novel splicing mutation in SLC9A6 in a boy with Christianson syndrome. Hum Genome Var. (2019) 6:15. doi: 10.1038/s41439-019-0046-x

12. Ilie A, Gao AYL, Boucher A, Park J, Berghuis AM, Hoffer MJV, et al. A potential gain-of-function variant of SLC9A6 leads to endosomal alkalinization and neuronal atrophy associated with Christianson Syndrome. Neurobiol Dis. (2019) 121:187-204. doi: 10.1016/j.nbd.2018.10.002
13. Ilie A, Boucher A, Park J, Berghuis AM, McKinney RA, Orlowski J. Assorted dysfunctions of endosomal alkali cation/proton exchanger SLC9A6 variants linked to Christianson syndrome. J Biol Chem. (2020) 295:707595. doi: 10.1074/jbc.RA120.012614

14. Pescosolido MF, Stein DM, Schmidt M, El Achkar CM, Sabbagh M, Rogg JM, et al. Genetic and phenotypic diversity of NHE6 mutations in Christianson syndrome. Ann Neurol. (2014) 76:581-93. doi: 10.1002/ana.24225

15. Mathieu ML, de Bellescize J, Till M, Flurin V, Labalme A, Chatron $\mathrm{N}$, et al. Electrical status epilepticus in sleep, a constitutive feature of Christianson syndrome? Eur J Paediatr Neurol. (2018) 22:112432. doi: 10.1016/j.ejpn.2018.07.004

16. Sinajon P, Verbaan D, So J. The expanding phenotypic spectrum of female SLC9A6 mutation carriers: a case series and review of the literature. Hum Genet. (2016) 135:841-50. doi: 10.1007/s00439-016-1675-5

17. Masurel-Paulet A, Piton A, Chancenotte S, Redin C, Thauvin-Robinet C, Henrenger $\mathrm{Y}$, et al. A new family with an SLC9A6 mutation expanding the phenotypic spectrum of Christianson syndrome. Am J Med Genet A. (2016) 170:2103-10. doi: 10.1002/ajmg.a.37765

18. Gong P, Xue J, Jiao X, Zhang Y, Yang Z. Genetic etiologies in developmental and/or epileptic encephalopathy with electrical status epilepticus during sleep: Cohort Study. Front Genet. (2021) 12:607965. doi: 10.3389/fgene.2021.6 07965

19. Coorg R, Weisenberg JL. Successful treatment of electrographic status epilepticus of sleep with felbamate in a patient with SLC9A6 mutation. Pediatr Neurol. (2015) 53:527-31. doi: 10.1016/j.pediatrneurol.2015. 07.007

20. Lizarraga SB, Ma L, Maguire AM, van Dyck LI, Wu Q, Ouyang $\mathrm{Q}$, et al. Human neurons from Christianson syndrome iPSCs reveal mutation-specific responses to rescue strategies. Sci Transl Med. (2021) 13:682. doi: 10.1126/scitranslmed.aaw0682

Conflict of Interest: The authors declare that the research was conducted in the absence of any commercial or financial relationships that could be construed as a potential conflict of interest.

Publisher's Note: All claims expressed in this article are solely those of the authors and do not necessarily represent those of their affiliated organizations, or those of the publisher, the editors and the reviewers. Any product that may be evaluated in this article, or claim that may be made by its manufacturer, is not guaranteed or endorsed by the publisher.

Copyright (C) 2022 Liu, Xie, Fang and Jiang. This is an open-access article distributed under the terms of the Creative Commons Attribution License (CC BY). The use, distribution or reproduction in other forums is permitted, provided the original author(s) and the copyright owner(s) are credited and that the original publication in this journal is cited, in accordance with accepted academic practice. No use, distribution or reproduction is permitted which does not comply with these terms. 